\title{
Behandling av idiopatisk pulmonal arteriell hypertensjon
}

\author{
Sammendrag \\ Bakgrunn. Den medikamentelle \\ behandling av idiopatisk pulmonal \\ arteriell hypertensjon har utviklet seg \\ betydelig de siste 5-10 år. Resultatene \\ fra slik oppdatert behandling er ikke \\ tidligere rapportert i Norge.
}

Materiale og metode. Resultater i hemodynamikk og fysisk kapasitet hos 32 konsekutivt nyutredede pasienter med idiopatisk pulmonal arteriell hypertensjon ble sammenliknet ved 3 og 12 måneders kontroll. Observert overlevelse ble sammenliknet med estimert overlevelse fra tiden hvor kun konvensjonell behandling var tilgjengelig.

Resultater. Pasientene (78\% kvinner) var $42 \pm 14$ år. De hadde dyspné $i$ NYHA- klasse $2,9 \pm 0,4$ og et maksimalt oksygenopptak på 12,0 $\pm 3,9 \mathrm{ml} / \mathrm{kg} / \mathrm{min}$ (37 $\pm 13 \%$ av forventet). Kontroller etter introduksjon av medisinsk behandling viste vedvarende signifikant bedret hemodynamikk og fysisk kapasitet. I løpet av gjennomsnittlig $43 \pm 31$ $(3,108)$ måneders oppfølging døde sju pasienter, mens to ble bilateralt lungetransplantert. Observert transplantasjonsfri overlevelse etter ett, to og tre år var $81 \%$, mens tilsvarende tall for estimert transplantasjonsfri overlevelse var henholdsvis $70 \%, 58 \%$ og $49 \%$.

Fortolkning. Oppdatert medikamentell behandling av idiopatisk pulmonal arteriell hypertensjon bedrer hemodynamikk med symptomlindring som følge. Dødeligheten forblir høy, men er sannsynligvis redusert sammenliknet med tiden før disse preparatene fantes.

\section{Arne K. Andreassen}

arne.andreassen@rikshospitalet.no

Kardiologisk avdeling

\section{Einar Gude}

Ole Geir Solberg

Kardiologisk avdeling

\section{Thor Ueland}

Institutt for indremedisinsk forskning

Oslo universitetssykehus, Rikshospitalet

Pulmonal arteriell hypertensjon er en kronisk og progressiv sykdom som karakteriseres av økt pulmonal vaskulær resistens, sekundært til hyperplasi av intima og hypertrofi av glatte muskelceller samt in situ trombose i små og mellomstore lungearterioler. Sykdommen kan forekomme som en komplikasjon til bindevevssykdommer, medfødte hjertelidelser, portal hypertensjon, hivinfeksjon eller etter inntak av anoreksiner eller amfetamin (1). Likeledes finnes en idiopatisk form for pulmonal arteriell hypertensjon uten assosiert sykdom. Den kan opptre sporadisk eller være arvelig, med en insidens på $1-2$ tilfeller per million per år. Diagnosen stilles ved eksklusjon av andre underliggende sykdommer. Før utviklingen av sykdomsspesifikke medikamenter var median overlevelse med denne lidelsen 2,8 år. Den langt vanligste dødsårsaken er progressiv høyresidig hjertesvikt $(2,3)$.

På grunnlag av randomiserte studier er det i løpet av de siste 5-10 år godkjent nye medikamenter i behandlingen av pulmonal arteriell hypertensjon: prostanoider, endotelinreseptorantagonister og fosfodiesterase5 -inhibitorer. Tabell 1 viser registrerte preparater i Norge. Internasjonale studier og meddelelser fra andre land tilsier at anvendelse av disse preparatene kan bedre hemodynamikk, funksjonsevne og eventuelt leveutsikter hos slike pasienter sammenliknet med konvensjonell behandling (diuretika, digitalis, antikoagulasjon og ev. kronisk oksygentilførsel) (4). Hensikten med denne artikkelen er å redegjøre for våre erfaringer med disse medikamentene $\mathrm{i}$ behandlingen av pasienter med idiopatisk pulmonal arteriell hypertensjon i Norge.

\section{Materiale og metode}

Fra desember 2002 til august 2009 har vi utredet mer enn 250 henviste pasienter eldre enn 18 år med pulmonal arteriell hypertensjon. Diagnosen idiopatisk pulmonal arteriell hypertensjon ble stilt hos 32 pasienter i henhold til kriteriene etablert av National Institute of Health (NIH)-registeret for denne sykdommen (2). Utredningen av pasientene er gjort i tråd med internasjonale retningslinjer som vi tidligere har beskrevet $i$ Tidsskriftet (5). Alle pasienter gjennomgikk ekkokardiografi, undersøkelse av lungefunksjon, røntgen av hjerte/lunger, CT thorax eller pulmonal angiografi, blodprøver med hivstatus, markører for bindevevssykdom og natriuretiske peptider $\mathrm{i}$ form av N-terminal pro-hjerne-natriuretisk peptid (NT-proBNP), kardiopulmonal testing av arbeidskapasitet med ergometersykling og høyresidig hjertekateterisering med akutt vasodilatasjonstest for avklaring av reversibilitet. Sistnevnte prosedyre ble utført med prostanoidet iloprost $\mathrm{i}$ inhalasjonsform. Våre erfaringer med denne teknikken er redegjort for tidligere (6). Etter oppstart av behandling ble pasientene innlagt på ny etter tre og 12 måneder. Klinisk undersøkelse, ekkokardiografi, høyresidig hjertekateterisering, blodprøver og ergometersykling ble gjentatt ved hver kontroll. Studien er godkjent av personvernombudet.

\section{Statistikk og analyse}

Avhengig av normalfordeling eller ikke, er alle verdier angitt i gjennomsnitt \pm standardavvik (SD) eller median (minimum - maksimum). Sammenlikning av kontinuerlige variabler mellom basismålinger og kontroll etter tre og 12 måneder ble utført med ANOVA-test for repeterte målinger. Statis-

\section{Hovedbudskap}

- Medikamenter som de siste årene er blitt godkjent for behandling av pulmonal arteriell hypertensjon synes å ha gunstige effekter ved idiopatisk sykdom

- Hos pasienter som ikke svarer på høydose kalsiumblokade vil medikamentene kunne bidra til avlastning og bedring av høyre ventrikkels funksjon

- Bedret hemodynamikk gir symptomlindring i form av mindre dyspné og bedre yteevne

- En bevarende effekt på høyre ventrikkel kan ligge til grunn for en sannsynlig overlevelsesgevinst etter introduksjonen av sykdomsspesifikke medikamenter 
Tabell 1 Medikamenter godkjent av Statens legemiddelverk for behandling av pulmonal arteriell hypertensjon

\begin{tabular}{llll} 
& & NYHA- \\
Medikamentgruppe & Preparat & klasse & Dosering \\
Endotelinreseptorantagonister & Ambrisentan & II, III & $5-10 \mathrm{mg} \times 1$ \\
& Bosentan & II, III & $125 \mathrm{mg} \times 2$ \\
Fosfodiesterase type-5-inhibitorer & Sildenafil & II, III & $20 \mathrm{mg} \times 3$ \\
\hline Prostanoider & $\begin{array}{l}\text { Epoprostenol (intravenøst) } \\
\text { lloprost (inhalasjon, }\end{array}$ & III, IV & $15-50 \mathrm{ng} / \mathrm{kg} / \mathrm{min}$ \\
& intravenøst) & III, IV & $10 \mu \mathrm{mg} \times 6-9$ \\
& $\begin{array}{l}\text { Treprostinil (intravenøst, } \\
\text { subkutant) }\end{array}$ & III & $20-60 \mathrm{ng} / \mathrm{kg} / \mathrm{min}$ \\
& & &
\end{tabular}

tisk signifikans ble definert som p-verdier $<0,05$. Tidspunktet for første høyresidige hjertekateterisering ble benyttet til bestemmelse av overlevelse, som ble kalkulert med Kaplan-Meier-estimater. Variabler relatert til utvikling av død eller lungetransplantasjon ble identifisert med Cox-regresjon og logistisk regresjonsanalyse og kun signifikante variabler ved univariat analyse ble inkludert i multivariatanalysen. Lungetransplanterte pasienter ble oppfattet til ikke å svare tilstrekkelig på medisinsk behandling og ble i den statistiske analysen gruppert blant de som døde. Forventet overlevelse ble utregnet for hver pasient ved hjelp av NIH-formelen $\mathrm{P}(\mathrm{t})=[\mathrm{H}(\mathrm{t})]^{\mathrm{A}(\mathrm{x}, \mathrm{y}, \mathrm{z})}$. Denne kalkulerer sannsynligheten for overlevelse $(\mathrm{P})$ angitt $\mathrm{i}$ år $(\mathrm{t})$, hvor $\mathrm{A}(\mathrm{x}, \mathrm{y}, \mathrm{z})=\mathrm{e}^{(0,007325 \mathrm{x}+0,0526 \mathrm{y}-0,3235 \mathrm{z})}, \mathrm{x}$ er middeltrykk i arteria pulmonalis, y er middeltrykk i høyre atrium og z er kardial indeks (3). Sannsynlighetene for overlevelse etter ett, to og tre år blir dermed: $\mathrm{P}(1)=0,75^{\mathrm{A}}$, $\mathrm{P}(2)=0,65^{\mathrm{A}}$ og $\mathrm{P}(3)=0,55^{\mathrm{A}}$. Formelen er senere validert $\mathrm{i}$ en prospektiv studie (7).

\section{Resultater}

To pasienter hadde startet med inhalasjon av ilomedin og ytterligere tre hadde begynt med sildenafil, mens de øvrige ikke tidligere hadde mottatt sykdomsspesifikk medikasjon ved første innleggelse i vår avdeling. Konvensjonell behandling i form av diuretika og warfarin var iverksatt ved henvisende sykehus hos henholdsvis 15 og 14 pasienter.

Frem til diagnosetidspunktet hadde pasientene hatt symptomer i $20 \pm 8$ måneder. Fem pasienter hadde førstegrads slektninger med tilsvarende sykdom og tre ulike familier ble således identifisert med familiær idiopatisk pulmonal arteriell hypertensjon. Ratioen kvinner: menn var $3: 1$. Alle anga å ha dyspné, 27 av pasientene var i New York Heart Association (NYHA)-klasse III, 14 anga brystsmerter ved anstrengelse, to hadde sykehistorie med synkope og 16 pasienter var henvist med væskeretensjon og synlige ødemer. Warfarin ble kontinuert/ startet hos alle dersom de ikke hadde blødningstendens, og diuretika ble gitt veiledet av kliniske funn og kateteriseringsfunn.

Etter endt utredning ble 11 pasienter satt på epoprostenol, levert fra bærbar pumpe via tunnelert sentralt venekateter med spiss til høyre atrium. Den praktiske gjennomføringen ved slik behandling er tidligere beskrevet i Tidsskriftet (4). Vedlikeholdsdose i denne gruppen var $32 \pm 10 \mathrm{ng} / \mathrm{kg} / \mathrm{min}$. En pasient ble behandlet etter samme prinsipper med treprostinil $40 \mathrm{ng} / \mathrm{kg} / \mathrm{min}$, mens tre andre fikk treprostinil subkutant $32 \pm 10 \mathrm{ng} / \mathrm{kg} / \mathrm{min}$ (abdominal kanyle og bærbar pumpe). Peroral behandling $\mathrm{i}$ form av bosentan $125 \mathrm{mg} \times 2$, ambrisentan $5 \mathrm{mg} \times 1 \mathrm{og}$ sildenafil $20 \mathrm{mg} \times 3$ ble gitt til henholdsvis seks, tre og 15 pasienter. Ni pasienter har etter hvert benyttet en kombinasjon av to eller tre midler. Ved akutt vasodilatasjonstesting var fire pasienter reversible og nær normaliserte middeltrykk i a. pulmonalis $(<30 \mathrm{~mm} \mathrm{Hg})$, samtidig økte minuttvolum ( $>4 \mathrm{l} / \mathrm{min}$ ) og lungekarmotstand falt således betydelig $(<5,5 \mathrm{~W})$. Disse ble oppfattet som kandidater for høydose kalsiumblokade, og senere oppfølginger har vist at de fikk genuin respons ved behandling med $90-120 \mathrm{mg}$ nifedipin daglig.

Bivirkninger i form av hodepine, ledd- og muskelsmerter og svimmelhet ble rapportert hos et flertall av pasientene behandlet med ett av de sykdomsspesifikke preparatene, oftest av moderat grad og med avtakende plager over tid etter oppstart. Peroral behandling var best tolerert. 11 av 12 som har fått prostanoider intravenøst via sentralt venekateter har måttet skifte kateter en eller flere ganger på grunn av løsning fra innstikkstedet. Seks tilfeller av kateterinfeksjoner har vært behandlet med antibiotika, midlertidig seponering av kateter og prostanoider via perifer vene, før reinnleggelse av sentralt venekateter. Ved subkutan treprostinilbehandling unngås potensielt livstruende infeksjoner, men lokal smerte fra innstikkstedet umuliggjør en slik administrasjonsform for alle som har behov for prostanoider.

Pasientenes hemodynamikk og fysiske kapasitet før oppstart av behandling er angitt $\mathrm{i}$ tabell 2. Samtlige hadde innkilt lungearterietrykk $\leq 12 \mathrm{~mm} \mathrm{Hg}$, som tydet på at de høye trykkene i lungekretsløpet ikke var passiv forplantning fra sviktende venstre ventrikler

Tabell 2 Kliniske karakteristika, funksjonsevne og hemodynamikk ved første gangs undersøkelse av 32 pasienter med idiopatisk pulmonal arteriell hypertensjon. Tall oppgitt som gjennomsnitt \pm standardavvik eller median (minimum-maksimum), dersom ikke annet er oppgitt

\begin{tabular}{|c|c|c|c|}
\hline & Alle & Overlevere & Døde/transplanterte \\
\hline & $(n=32)$ & $(n=23)$ & $(n=9)$ \\
\hline Alder (år) & $42 \pm 14$ & $40 \pm 12$ & $48 \pm 18$ \\
\hline Kjønn (kvinne/mann) & $25 / 7$ & $19 / 4$ & $6 / 3$ \\
\hline NYHA-klasse & $2,9 \pm 0,4$ & $2,8 \pm 0,4$ & $3,2 \pm 0,4$ \\
\hline $\mathrm{O}_{2}$-opptak (ml/kg/min) & $12,0 \pm 4,0$ & $13,1 \pm 4,0$ & $8,9 \pm 2,7$ \\
\hline N-terminal pro-hjerne-natriuretisk peptid (pmol/l) & $282(13-2440)$ & $257(13-670)$ & $382(155-2440)$ \\
\hline \multicolumn{4}{|l|}{ Hemodynamikk } \\
\hline Middeltrykk i høyre atrium (mm Hg) & $6(0-14)$ & $5(0-14)$ & $10(2-14)$ \\
\hline Systolisk trykk i a. pulmonalis (mm Hg) & $90 \pm 20$ & $89 \pm 18$ & $93 \pm 27$ \\
\hline Middeltrykk i a. pulmonalis (mm Hg) & $57 \pm 13$ & $56 \pm 11$ & $60 \pm 16$ \\
\hline Innkilt lungearterietrykk (mm Hg) & $7(1-12)$ & $6(1-12)$ & $7(2-11)$ \\
\hline Minuttvolum/kardial indeks $\left(\mathrm{l} / \mathrm{min} / \mathrm{l} / \mathrm{min} / \mathrm{m}^{2}\right)$ & $3,3 \pm 0,9 / 1,8 \pm 0,5$ & $3,4 \pm 0,9 / 1,9 \pm 0,5$ & $2,9 \pm 0,5 / 1,6 \pm 0,3$ \\
\hline Lungekarmotstand (Wood-enheter) & $16,1 \pm 5,2$ & $15,3 \pm 4,6$ & $18,4 \pm 6,4$ \\
\hline Oksygenmetning i a. pulmonalis (\%) & $58,6 \pm 8,8$ & $53,3 \pm 6,3$ & $60,6 \pm 8,8$ \\
\hline
\end{tabular}



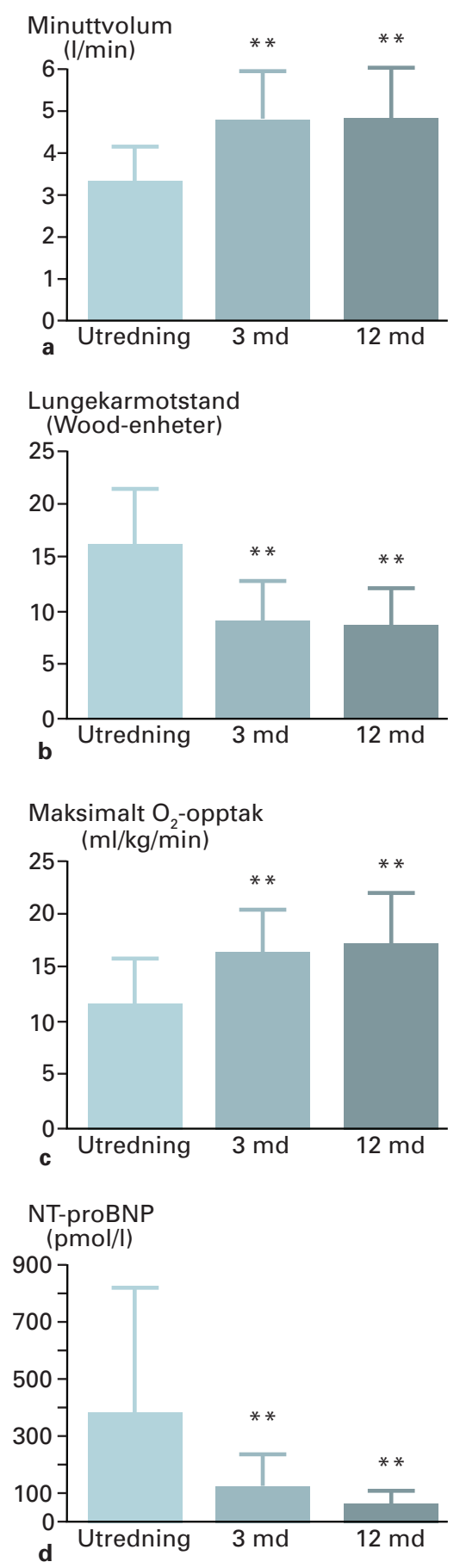

Figur 1 Endringerial minuttvolum, b) lungekarmotstand, cl maksimalt oksygenopptak og d) NTproBNP tre $(n=29)$ og 12 måneder $(n=27)$ etter oppstart av medisinsk behandling hos 32 pasienter med idiopatisk pulmonal arteriell hypertensjon ${ }^{* *} p<0,01$ for sammenlikning av variabler ved tidspunktet for utredning med tre og 12 måneders kontroll

som ved ordinær hjertesvikt (postkapillær pulmonal hypertensjon, gruppe $2 \mathrm{i}$ henhold til WHOs inndeling av pulmonal hypertensjon (4)). Påvisning av høyre ventrikkelsvikt sekundært til økt pulmonal resistens ble gjort ved invasiv måling av redusert minuttvolum og kompensatorisk økt hjertefrekvens, biokjemisk ved påvisning av økt serum NTproBNP og ekkokardiografisk ved påvisning av hypertrofi, dilatasjon og hypokinesi av høyre ventrikkel. Fysisk kapasitet bedømt med ergometri viste et maksimalt oksygenopptak som utgjorde $37 \pm 13 \%$ av forventet kapasitet justert for kjønn, vekt og alder.

\section{Tre og 12 måneders kontroll}

En klar funksjonsmessig bedring etter oppstart av medisinsk behandling ble registrert etter tre måneder, med reduksjon i NYHAklasse for dyspné (fra 2,9 $\pm 0,4$ til 2,0 $\pm 0,3$; $\mathrm{p}<0,001)$ og en gjennomsnittlig økning av maksimalt oksygenopptak med $35 \pm 13 \%$ (fra $12,1 \pm 3,9 \mathrm{ml} / \mathrm{kg} / \mathrm{min}$ til $16,3 \pm 4,6 \mathrm{ml} /$ $\mathrm{kg} / \mathrm{min} ; \mathrm{p}<0,001)$. I tillegg ble det påvist en reduksjon i NT-proBNP med $56 \pm 55 \%$ (fra 339 (13-2 440) pmol/1 til 149 (12-1 090) $\mathrm{pmol} / \mathrm{l} ; \mathrm{p}<0,001)$ og bedring av høyresidige hjertekateteriseringsdata, som etter tre måneder inkluderte $46 \pm 6 \%$ økning i minuttvolum (fra $3,3 \pm 0,71 / \mathrm{min}$ til 4,7 $\pm 1,2 \mathrm{l} / \mathrm{min}$; $\mathrm{p}<0,001), 21 \pm 20 \%$ reduksjon i gjennomsnittlig lungearterietrykk (fra $57 \pm 13 \mathrm{mmHg}$ til $45 \pm 10 \mathrm{mmHg}$; $<<0,001), 44 \pm 30 \%$ reduksjon i lungekarmotstand (fra 16,1 $\pm 5,2$ Wood-enheter til 9,3 \pm 4,2 Wood-enheter; $\mathrm{p}<0,001)$ og $13 \pm 12 \%$ økning i oksygenmetning i blandet venøst blod (fra 58,4 \pm $7,7 \%$ til $66,1 \pm 6,4 \% ; p<0,001$ ) (fig 1 ). Disse funnene var ikke signifikant endret ved 12-måneders kontroll.

\section{Overlevelse}

Med en observasjonstid på $43 \pm 31$ måneder døde sju pasienter og to ble satt på venteliste og senere bilateralt lungetransplantert. Forverring av høyre ventrikkel-svikt til tross for optimal medisinsk behandling betinget henvisning til transplantasjon og lå til grunn for samtlige dødsfall. Univariat Cox-regresjonsanalyse ved førstegangs undersøkelse identifiserte høy NYHA- funksjonsklasse, høye NT-proBNP-verdier og lave verdier for maksimalt oksygenopptak, indeksert minuttvolum og metning i blandet venøst blod som risikofaktorer for mortalitet. Ved multivariat analyse var det kun maksimalt oksygenopptak som var en uavhengig risikofaktor for mortalitet, med en justert risikoratio på $0,66(95 \%$ konfidensintervall $0,49-0,90$; $\mathrm{p}=0,008)$.

Etter ett, to og tre år var $81 \%$ av pasientene fortsatt i live uten å ha gjennomgått lungetransplantasjon (67\% ved fem år). De lungetransplanterte lever også fortsatt. Benyttes den såkalte $\mathrm{NIH}$-formelen med innlemming av hemodynamiske variabler fra diagnosetidspunktet for hver enkelt pasient (3), finner vi at den estimerte overlevelsen ved konvensjonell behandling var $70 \%, 58 \%$ og $49 \%$ for tilsvarende tidspunkter for oppfølging (fig 2).

\section{Diskusjon}

Langtidsoppfølging av pasienter med idiopatisk pulmonal arteriell hypertensjon er ikke tidligere omtalt i Norge, og det eksisterer relativt få internasjonale rapporter. Vi finner at oppdatert medisinsk behandling

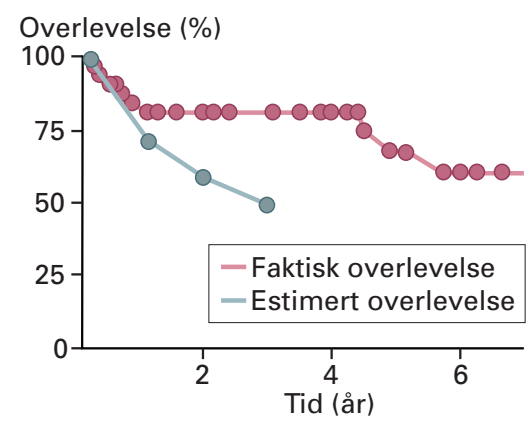

Figur 2 Transplantasjonsfri faktisk og estimert overlevelse blant 32 pasienter med idiopatisk pulmonal arteriell hypertensjon

reduserer symptomer sekundært til bedring av hemodynamikk med bevaring av høyre ventrikkel-funksjon. Sammenliknet med estimert overlevelse for hver enkelt pasient fra æraen med konvensjonell behandling, synes det medisinske vasodilaterende tilbudet av i dag å gi en overlevelsesgevinst.

Med hensyn til kvinneandel, grad av dyspné, hemodynamikk eller fysisk kapasitet, skiller ikke vår henviste pasientkohort seg vesentlig fra andre meddelelser om slike pasienter $(3,7)$. Pasientene hadde symptomer i gjennomsnitt mer enn ett og et halvt år før diagnosetidspunktet. Dette synliggjør problemet med relativt uspesifikke plager og en sjelden lidelse. Det er nylig påvist at tidlig diagnose og oppstart av medisinsk behandling utsetter tid til klinisk forverring som hospitalisering, komplikasjoner og død (8). Således utfordres årvåkenheten hos leger. En kombinasjon av røntgen thorax, ekkokardiografi, måling av fysisk kapasitet og blodprøver som inkluderer natriuretiske peptider, kan fungere godt som verktøy for screening.

Vår påvisning av tre familier med hereditær form av sykdommen passer med en beskrevet forekomst av 5-10\% blant dem med idiopatisk pulmonal arteriell hypertensjon (1). Arvegangen er autosomalt dominant med inkomplett penetrans og genetisk antisipasjon, og hos 50-90\% av pasientene foreligger en mutasjon i beinmorfogeneseproteinreseptor 2 (9). Genet er sentralt i moduleringen av vaskulær cellevekst og er således foreslått implisert i patogenesen ved hereditær pulmonal arteriell hypertensjon, men det gjenfinnes sjeldent ved andre former for pulmonal arteriell hypertensjon. Som ved aterosklerose og kreft er det foreslått en multifaktoriell genese (10).

Langtidsoppfølging viser at de fire pasientene som nærnormaliserte sin hemodynamikk ved akutt vasodilatsjonstest er genuine respondere på høydosebehandling med kalsiumantagonister. Slike pasienter har vist seg å ha en meget god prognose (11). Deres pulmonale arterioler kjennetegnes av beskjedne strukturelle forandringer og endoteldysfunksjon med vasokonstriksjon, hvor kalsiumantagonister reduserer kartonus ved 
å hemme cellulær influks av kalsiumioner. Høyre ventrikkels funksjon vil bedres som følge av tilnærmet normale trykk i lungekarene etter et fall i lungekarmotstanden. De resterende pasientene kan klinisk ikke skilles fra disse, men har etablerte strukturelle forandringer i lungearteriolene med fibrose og hyperplasi av endotelceller og hypertrofi av glatt muskulatur i åreveggen (10). Verken akutt vasodilatasjonstesting under høyre kateterisering eller den kroniske behandlingen de mottar, evnet å redusere trykkene i lungekarene med mer enn 10-20\%. Denne lavgradige trykkreduksjonen vil imidlertid, sammen med en eventuell inotrop effekt av virkestoffet, gi en ikke ubetydelig økning i minuttvolum. Hvorvidt bedret høyre ventrikkelfunksjon også kan skyldes reversering av strukturelle vaskulære forandringer er usikkert, selv om dyreeksperimentelle data kan tyde på at $\mathrm{i}$ hvert fall prostanoider og sildenafil har slike effekter $(12,13)$.

Preparatvalg ved oppstart av behandling hos ikke-respondere ved akutt vasodilatasjonstest baseres på alvorlighetsgrad av sykdommen. Peroral behandling forsøkes hos dem som ikke er i NYHA-klasse IV eller som etter en totalvurdering i klasse III har en rimelig prognose. Økning i levertransaminaser ved bruk av endotelinantagonister ses hos inntil $10 \%$ av pasientene. Derfor anbefales månedlig kontroll av leverenzymer, med seponering eller reduksjon i dosen ved ASAT/ALAT-stigning til 3-5 ganger øvre normalgrense. En av våre pasienter måtte seponere bosentan innen tre måneder etter oppstart, mens en annen har greid seg med halvering av dosen. Prostanoider reserveres de sykeste og pasienter som ved kontroll ikke viser hemodynamisk og funksjonsmessig fremgang (14). Kombinasjonsbehandling vurderes da til samme tid i henhold til internasjonale retningslinjer (4).

Vår påvisning av at fysisk yteevne bedømt med maksimalt oksygenopptak ved førstegangs undersøkelse har uavhengig prediktiv evne for mortalitet, er i tråd med andres funn (15). I tillegg har andre studier vist at hemodynamikk bedømt med høyresidig kateterisering (3), enkelte ekkokardiografiske indekser (16), NYHA-funksjonsklasse (17) og biomarkører som troponiner (18) og NTproBNP (19) kan ha prognostisk betydning. Oppfølging inkluderer derfor undersøkelser som gir «flerdimensjonal» informasjon om responsen av iverksatt behandling og behovet for eskalering av denne.

Tatt i betraktning alvorlighetsgraden av sykdommen og de høye medikamentkostnadene (årlige utgifter fra 66000 kroner for sildenafil til vel 1 million kroner for prostanoider, avhengig av bl.a. vekt), er det bemerkelsesverdig at det blant godkjente medikamenter for pulmonal arteriell hypertensjon kun er epoprostenol som i randomiserte studier har vist en overlevelsesgevinst (14). Den typiske designen på studiene har vært en randomisering over 12-16 uker med seks minutters gangtest som det primære endepunktet. Sammenholdt med historiske kontrollpersoner har man i ublindede forlengelsesstudier funnet økt overlevelse ved perorale preparater $(20,21)$. Likeledes konkluderte man i en nylig publisert metaanalyse med over 3000 pasienter fra 21 randomiserte studier med en $43 \%$ signifikant reduksjon i totalmortalitet, med gjennomsnittlig oppfølging i bare 14,3 uker og 3,8\% mortalitet i kontrollgruppen (22). Disse rapportene støtter vår observasjon $\mathrm{av}$ en bedret overlevelse blant dem som får oppdatert sykdomsspesifikk medikamentell behandling. Funnene er gjort ved sammenlikning med historiske kontrollpersoner på en tid da kun konvensjonell behandling var tilgjengelig, og må således tolkes med forsiktighet. Formelen benyttet for utregning av estimert overlevelse er imidlertid brukt og validert prospektive studier (6), og vår egen pasientgruppes karakteristika tyder på like alvorlig sykdom som i disse arbeidene.

\section{Arne K. Andreassen (f. 1956)}

er dr.med. og kardiolog. Han er overlege ved Kardiologisk avdeling, Oslo universitetssykehus, Rikshospitalet, med ansvar for hjertetransplantasjon ved avdelingen.

Oppgitte interessekonflikter: Har mottatt kongresstøtte til og honorar for forelesninger om pulmonal arteriell hypertensjon fra Pfizer, GlaxoSmithKline, Actelion/Swedish Orphan og United Therapeutics.

\section{Einar Gude (f. 1968)}

er spesialist i indremedisin og i hjertesykdommer. Han er overlege ved Hjertemedisinsk avdeling. Oslo universitetssykehus, Rikshospitalet, med ansvar for hjertetransplantasjon og assistert sirkulasjon.

Ingen oppgitte interessekonflikter.

\section{Ole Geir Solberg (f. 1956)}

er spesialist i allmennmedisin, spesialist $i$ indremedisin og i kardiologi. Han er overlege ved Kardiologisk avdeling, Oslo universitetssykehus, Rikshospitalet.

Ingen oppgitte interessekonflikter.

\section{Thor Ueland (f. 1969)}

er ph.d. Han er gruppeleder for gruppe med fokus på endokrinologi, inflammasjon og kardiovaskulær sykdom inkludert biomarkører ved Institutt for indremedisinsk forskning. Oslo universitetssykehus, Rikshospitalet. Ingen oppgitte interessekonflikter.

\section{Litteratur}

1. Chin KM, Rubin LJ. Pulmonary arterial hypertension. J Am Coll Cardiol 2008. 51: 1527-38. 2. Rich S, Dantzker DR, Ayres SM et al. Primary pulmonary hypertension. A national prospective study. Ann Intern Med 1987; 107: 216-23.

3. D'Alonzo GE, Barst RJ, Ayres SM et al. Survival in patients with primary pulmonary hypertension. Results from a national prospective registry. Ann Intern Med 1991; 115: 343-9.
Galiè N, Hoeper MM, Humbert M et al. Guidelines for the diagnosis and treatment of pulmonary hypertension: the Task Force for the Diagnosis and Treatment of Pulmonary Hypertension of the European Society of Cardiology (ESC) and the European Respiratory Society (ERS), endorsed by the International Society of Heart and Lung Trans plantation (ISHLT. Eur Heart J 2009; 30: 2493-537.

5. Andreassen AK, Geiran O, Madsen S et al. Pulmo nal arteriell hypertensjon behandlet med prostasyklin eller kalsiumblokade. Tidsskr Nor Lægeforen 2003; 123: 3393-6.

6. Andreassen AK, Madsen S, Kjekshus J et al. Inhalasjon av en prostasyklinanalog (iloprost) ved primær og sekundær pulmonal hypertensjon. Tidsskr Nor Lægeforen 2001; 121: 1220-3.

7. Sandoval J, Bauerle O, Palomar A et al. Survival in primary pulmonary hypertension. Validation of a prognostic equation. Circulation 1994: 89 1733-44.

8. Galiè N, Rubin Lj, Hoeper M et al. Treatment of patients with mildly symptomatic pulmonary arterial hypertension with bosentan (EARLY study) a double-blind, randomised controlled trial. Lancet 2008; 371: 2093-100.

9. Machado RD, Pauciulo MW, Thomson JR et al. BMPR2 haploinsufficiency as the inherited molecular mechanism for primary pulmonary hypertension. Am J Hum Genet 2001; 68: 92-102.

10. Humbert M, Morrell NW, Archer SL et al. Cellular and molecular pathobiology of pulmonary arterial hypertension. J Am Coll Cardiol 2004; 43 (suppl S) 13S-24S.

11. Sitbon O, Humbert M, Jaïs X et al. Long-term response to calcium channel blockers in idiopathic pulmonary arterial hypertension. Circulation 2005 111: 3105-11

12. Tantini B, Manes A, Fiumana E et al. Antiproliferative effect of sildenafil on human pulmonary artery smooth muscle cells. Basic Res Cardiol 2005; 100 $131-8$

13. Jones DA, Benjamin CW, Linseman DA. Activation of thromboxane and prostacyclin receptors elicits opposing effects on vascular smooth muscle cell growth and mitogen-activated protein kinase signaling cascades. Mol Pharmacol 1995; 48: 890-6.

14. Barst RJ, Rubin LJ, Long WA et al. A comparison of continuous intravenous epoprostenol (prostacyclin) with conventional therapy for primary pulmonary hypertension. N Engl J Med 1996; 334: 296-302

15. Wensel R, Opitz CF, Anker SD et al. Assessment of survival in patients with primary pulmonary hyper tension: importance of cardiopulmonary exercise testing. Circulation 2002; 106: 319-24.

16. Raymond RJ, Hinderliter AL, Willis PW et al. Echo cardiographic predictors of adverse outcomes in primary pulmonary hypertension. J Am Coll Cardiol 2002; 39: 1214-9.

17. Sitbon $\mathrm{O}$, Humbert $\mathrm{M}$, Nunes $\mathrm{H}$ et al. Long-term intravenous epoprostenol infusion in primary pulmonary hypertension: prognostic factors and survival. J Am Coll Cardiol 2002; 40: 780-8.

18. Torbicki A, Kurzyna M, Kuca P et al. Detectable serum cardiac troponin $T$ as a marker of poor prognosis among patients with chronic precapillary pulmonary hypertension. Circulation 2003; 108: $844-8$

19. Andreassen AK, Wergeland R, Simonsen $S$ et al. $\mathrm{N}$-terminal pro-B-type natriuretic peptide as an indicator of disease severity in a heterogeneous group of patients with chronic precapillary pulmo nary hypertension. Am J Cardiol 2006; 98: 525-9.

20. McLaughlin VV, Sitbon O, Badesch DB et al. Survival with first-line bosentan in patients with primary pulmonary hypertension. Eur Respir J 2005; 25 $244-9$.

21. Oudiz RJ, Galiè N, Olschewski H et al. Long-term ambrisentan therapy for the treatment of pulmonary arterial hypertension. J Am Coll Cardiol 2009; 54: $1971-81$

22. Galiè N, Manes A, Negro L et al. A meta-analysis of randomized controlled trials in pulmonary arterial hypertension. Eur Heart J 2009: 30 : $394-403$

Mottatt 15.1. 2010, første revisjon innsendt 22.6 2010, godkjent 3.2. 2011. Medisinsk redaktør Are Brean. 